\title{
References
}

Hof, G., H. Boer \& P. J. Lenaers, 1984. Celwanden, parameters voor de ruwvoederopname? Landbouwkundig Tijdschrift $96(6): 25-28$.

Kies, A. K., J. van Bruchem, G. Hof \& H. Boer, 1986. The digestion of grass and alfalfa silages in the forestomachs and intestines of sheep. Netherlands Journal of Agricultural Science 34: 119-122.

Mehrez, A. Z. \& E. R. Ørskov, 1977. A study of the artificial fibre bag technique for determining the digestibility of feeds in the rumen. Journal of Agricultural Science, Cambridge 88: 645-650.

This synopsis is based on an undergraduate thesis entitled 'De in sacco afbraak van een gras-, luzerne- en snijmaissilage' by R. P. Kwakkel, Department of Animal Physiology, Agricultural University, Wageningen, 1985. 84 pp., 12 figs., 19 tables, 58 refs., 13 appendices. Dutch.

Available as paper copy (order R050P, $f 30$ including postage) or microfiche (order R050M, f 12.50 including postage) at: NARD, c/o Pudoc, P.O. Box 4, 6700 AA Wageningen, Netherlands (telex 45015 blhwg).

\section{The digestion of grass and alfalfa silages in the forestomachs and intestines of sheep}

A. K. Kies ${ }^{1,2}$, J. van Bruchem ${ }^{1}$, G. Hof ${ }^{2}$ and H. Boer ${ }^{2}\left({ }^{1}\right.$ Department of Animal Physiology, Agricultural University, Haarweg 10, 6709 PJ Wageningen, Netherlands; ${ }^{2}$ Department of Animal Nutrition, Agricultural University, Haagsteeg 4, 6708 PM Wageningen, Netherlands)

Received 13 January 1986; accepted 24 February 1986

\begin{abstract}
In wethers fitted with cannulas in the dorsal rumen sac and the small intestine, the digestion process of cell wall constituents and protein was followed of a grass and alfalfa (lucerne) silage, containing on a dry matter basis $12.9 \%$ crude protein (CP), $60.2 \%$ neutral detergent fibre (NDF) and $19.1 \% \mathrm{CP}, 48.8 \% \mathrm{NDF}$, respectively. Intake was 46.5 and $49.0 \mathrm{~g} \mathrm{DM} \mathrm{kg}^{-3 / 4} \mathrm{day}^{-1}$, respectively. In the reticulorumen the retention time of the fluid phase and particulate phase, with CoEDTA and CrNDF as a marker respectively, were estimated. The digestion of the cell wall constituents was investigated in the forestomachs and in the hind gut. Both protein degradation and microbial protein synthesis were estimated in the forestomachs and subsequently the digestion of protein in the intestines.

Key words: cell wall constituents, cellulose, hemicellulose, lignin, protein degradation, amino acids, retention time, microbial protein synthesis.
\end{abstract}

Introduction. The voluntary intake of roughages in ruminants is assumed to be restricted by the capacity of the reticulorumen. Hence the extent of degradation and 
the passage rate of undegraded particles are primarily determining the intake of a roughage.

In the present experiments both parameters were determined of a grass and an alfalfa (lucerne) silage fed almost ad libitum. In silages a considerable part of $\mathrm{N}$ is present as non-protein $\mathrm{N}$. The protein is regarded to be easily degradable. The fate of both $\mathrm{N}$ sources was studied in detail in both the reticulorumen and the intestines. Microbial protein synthesis was estimated based on the amino acid profiles of dietary, duodenal and microbial proteins. In the small intestine the apparent and true digestibility of the protein was regarded. Of these silages, the voluntary intake was determined in steers as well. For the grass and alfalfa silages, the daily intakes were 88.2 and $105.2 \mathrm{~g} \mathrm{DM} / \mathrm{kg}^{3 / 4}$ (Hof et al., 1984). The in sacco degradability of these silages was reported by Kwakkel et al. (1986).

Materials and methods. First-cut wilted grass and alfalfa silages (June 1983; composition as given by Kwakkel et al., 1986) were fed to 4 Texel wethers, provided with cannulas in the dorsal rumen sac, the proximal duodenum and the terminal ileum, and with an infusion tube into the abomasum. For the grass and alfalfa silage the daily intakes were 46.5 and $49.0 \mathrm{~g} \mathrm{DM} / \mathrm{kg}^{3 / 4}$.

Feed was supplied in 6 equal portions, with intervals of 4 hours. In the rumen the retention time of the fluid phase was determined with CoEDTA $(100 \mathrm{ml}$, ca. $5 \mathrm{~g}$ $\mathrm{Co} / \mathrm{l})$, and of the particulate phase with CrNDF $(10 \mathrm{~g}, 0.2-1.0 \mathrm{~mm}, \mathrm{ca} .5 \% \mathrm{Cr})$. Rumen contractions were recorded with an open-tip catheter. Passage rates of cell wall constituents and protein in the small intestine were calculated based on CoED$\mathrm{TA}$, infused continuously into the abomasum $(20 \mathrm{ml} / \mathrm{h}$, ca. $0.5 \mathrm{mg} \mathrm{Co} / \mathrm{ml})$. The values of cellulose, hemicellulose and lignin were derived from those of neutral detergent fibre (NDF), acid detergent fibre (ADF) and acid detergent lignin (ADL).

Results and discussion. Of the fluid fase, the highest rate of emptying of the reticulorumen was obtained with the grass silage (Table 1). Concomittantly a higher frequency of rumen contractions was found. Of the particulate phase, however, the rates of emptying did not differ significantly between both silages.

Of the cell wall constituents (CWC), the extent of degradation in the reticulorumen was higher for cellulose than for hemicellulose (Table 2). The overall digestibilities showed a comparable order, lignin being least digestible. CWC of the alfalfa silage were less digestible than those of the grass silage, probably as a result of the higher lignin content of alfalfa silage. These results were in line with those obtained in sacco by Kwakkel et al. (1986). The passage rates of crude protein in the duode-

Table 1. Fractional emptying rate $(\% / \mathrm{h})$ of the liquid $(\mathrm{L})$ and particulate phase $(\mathrm{P})$ from the reticulorumen and the frequency $(F)$ of rumen contractions $\left(\mathrm{h}^{-1}\right)$ with grass and alfalfa silage.

\begin{tabular}{lccc}
\hline & Grass & Alfalfa & SEM \\
$\mathrm{L}$ & 5.7 & 4.9 & 0.14 \\
$\mathrm{P}$ & 3.8 & 4.0 & 0.13 \\
$\mathrm{~F}$ & 127 & 101 & 12.4 \\
\hline
\end{tabular}


Table 2. Intake, passage in the small intestine and excretion into the faeces of cell wall constituents and crude protein $(\mathrm{N} \times 6.25)(\mathrm{g} /$ day) with grass $(\mathrm{G})$ and alfalfa silage $(\mathrm{A})$.

\begin{tabular}{|c|c|c|c|c|c|}
\hline & & Intake & Duodenum $(\% \mathrm{I})^{1}$ & $\operatorname{Ileum}(\% \mathrm{D})^{1}$ & Faeces $(\% \mathrm{I})$ \\
\hline Crude protein & $\begin{array}{l}\text { G } \\
\text { A } \\
\text { SEM }\end{array}$ & $\begin{array}{l}123 \\
240\end{array}$ & $\begin{array}{c}175(142) \\
173(72) \\
4.2\end{array}$ & $\begin{array}{l}77 \quad(44) \\
91 \quad(53) \\
3.1\end{array}$ & $\begin{array}{c}62 \quad(51) \\
74 \quad(31) \\
2.2\end{array}$ \\
\hline Cellulose & $\begin{array}{l}\text { G } \\
\text { A } \\
\text { SEM }\end{array}$ & $\begin{array}{l}363 \\
389\end{array}$ & $\begin{array}{c}108 \\
186 \\
7.4\end{array}\left(\begin{array}{l}(30) \\
(48)\end{array}\right.$ & & $\begin{array}{c}88 \quad(24) \\
165 \quad(42) \\
3.8\end{array}$ \\
\hline Hemicellulose & $\begin{array}{l}\text { G } \\
\text { A } \\
\text { SEM }\end{array}$ & $\begin{array}{r}292 \\
93\end{array}$ & $\begin{array}{r}119(41) \\
88(95) \\
2.8\end{array}$ & & $\begin{array}{l}87 \quad(30) \\
66 \quad(72) \\
3.2\end{array}$ \\
\hline Lignin & $\begin{array}{l}\text { G } \\
\text { A } \\
\text { SEM }\end{array}$ & $\begin{array}{r}39 \\
120\end{array}$ & $\begin{array}{r}31 \\
106 \\
2.6\end{array}$ & & $\begin{array}{r}35 \\
104 \quad(80) \\
1.9\end{array}$ \\
\hline
\end{tabular}

$1 \% \mathrm{I}: \%$ of intake; \% D: \% of duodenal passage.

num did not differ significantly between the silages, despite the considerably higher content of crude protein in the alfalfa silage. Based on the amino acid profiles of dietary, duodenal and microbial proteins, an extent of degradation of dietary crude protein in the reticulorumen of 64 and $87 \%$ was estimated for grass and alfalfa silage, respectively. The higher degradability of the alfalfa crude protein is probably caused by its higher solubility (Kwakkel et al., 1986).

Protein digestion in the small intestine showed to be lowest for the alfalfa silage. This is probably not a result of a lower true digestibility. In comparison with the digestibilities reported by van Bruchem et al. (1985) with rations composed of hay and mixed concentrates, the present apparent digestibilities were lower at comparable duodenal passage rates of protein. This is probably caused by the higher flow of dry matter in the small intestine, especially with aflfala silage, causing an increased flow of endogenous protein in the small intestine.

\section{References}

Bruchem, J, van, L. J. G. M. Bongers, J. D. van Walsem, W. Onck \& P. W. M. van Adrichem, 1985. Digestion of proteins of varying degradability in sheep. 3. Apparent and true digestibility in the small intestine and ileal endogenous flow of $\mathrm{N}$ and amino acids. Netherlands Journal of Agricultural Science 33: 285-295.

Hof., G., H. Boer \& P. J. Lenaers, 1984. Celwanden, parameters voor de ruwvoederopname? Landbouwkundig Tijdschrift 96/6: 25-28.

Kwakkel, R. P., J. van Bruchem, G. Hof en H. Boer, 1986. The in sacco degradation of crude protein and cell wall constituents in grass, alfalfa and maize silages. Netherlands Journal of Agricultural Science 34: 116-119. 
A. K. KIES ET AL.

This synopsis is based on an undergraduate thesis entitled 'De verteringsgang van celwandbestanddelen en eiwit in een gras-en luzernesilage bij schapen', Department of Animal Physiology, Agricultural University, Wageningen, 1985. 155 pp., 29 figs., 29 tables, 89 refs., 6 appendices. Dutch.

Available as paper copy (order R051P, $f 50$ including postage) or microfiche (order R015M, f 17.50 including postage) at: NARD, clo Pudoc, P.O. Box 4, 6700 AA Wageningen, Netherlands (telex $45015 \mathrm{blhwg}$ ). 